\title{
The structure of mangrove communities in response to water quality in Jakarta Bay, Indonesia
}

\author{
NILAM SARI ${ }^{1,2,}$, MUFTI P. PATRIA ${ }^{2}$, TRI EDHI BUDHI SOESILO ${ }^{3}$, IWAN GUNAWAN TEJAKUSUMA ${ }^{4}$ \\ ${ }^{1}$ Sekolah Tinggi Teknologi Industri Bontang (STTIB). Jl. Brigjend.Katamso No. 40, Bontang, East Kalimantan, Indonesia. \\ Tel.: +62-548-21512, "email: ninanilamsari.ns@gmail.com \\ ${ }^{2}$ Department of Biology, Faculty of Mathematics and Natural Science, Universitas Indonesia. Jl. Lingkar UI, E Building, Depok, West Java, Indonesia \\ ${ }^{3}$ Program in Environmental Science, School of Graduates, Universitas Indonesia, Jl. Salemba Raya No. 4, Jakarta Pusat 10430, Jakarta, Indonesia \\ ${ }^{4}$ Agency for Assessment and Application of Technology. J1. MH. Thamrin No. 8, Jakarta Pusat 10340, Jakarta, Indonesia
}

Manuscript received: 11 March 2019. Revision accepted: 17 June 2019.

\begin{abstract}
Sari N, Patria MP, Soesilo TEB, Tejakusuma IG. 2019. The structure of mangrove communities in response to water quality in Jakarta Bay, Indonesia. Biodiversitas 20: 1873-1879. The waters of Jakarta Bay, which is a habitat for mangrove vegetation, have been polluted caused by many human activities such as development of housing, industry, tourism and facilities along the coast, and reclamation of man-made islands. The islands reclamation has caused changes in ocean current pattern and has impacts on material mobilization in the waters. The mangroves have experienced degradation as well since long time ago. The purpose of this research was to investigate the responses of mangrove vegetation to the quality of water in disturbed areas in Jakarta Bay to be used as baseline information for mangrove forest management in the area. Analysis of vegetation was used to examine mangrove community structure with the results were then related to the measurements on water quality using simulation modeling. The results show that mangrove forests in Jakarta Bay have an average Important Value Index (IVI) for all levels of life stage $95.7 \%$ with relative density of $28.85 \%$, relative frequency of $29.21 \%$, and closure relative of $38.62 \%$. These results indicate that the mangrove forests in Jakarta Bay are under the criteria of damaged or disturbed according to the Minister of Environment Regulation. The mangrove forests were dominated by Avicennia marina, Avicennia lanata, Rhizophora apiculata, Sonneratia caseolaris, and Sonneratia alba. The average of ocean current velocity was $0.04-0.08 \mathrm{~m} / \mathrm{s}$. tides were single type with short waves generated by wind. The water discharge from 13 rivers were $205 \pm$ $97 \mathrm{~m}^{3} / \mathrm{s}$ and the water discharge from power plant $224.9 \mathrm{~m}^{3} / \mathrm{s}$. The heavy metal whereas The average pH was 7.75; Dissolved Oxygen $4.68 \mathrm{mg} / \mathrm{L}$; turbidity $5 \mathrm{~m}$; Total Suspended Solid (TSS) $50.95 \mathrm{mg} / \mathrm{L}$; and salinity $6.6 \%$. The result of grain size analysis showed that most sediments obtained was in the form of silt with a mixture of little clay and sand. The responses showed that there was a reinforced pattern for $\mathrm{pH}$, temperatures, rainfall, brightness, sediment, DO, and ocean current, with a trend of exponential growth in two years next of important value index of mangroves in response to water quality in Jakarta Bay. The heavy metals of $\mathrm{Pb}$ have concentrations of $65-$ $104 \mathrm{ppm}$ in sediments and 38-60 ppm in the water column; $\mathrm{Zn}$ has 150-258 ppm in sediment and 42-140 ppm in water column; Cu has 34-72 ppm in sediment and 13-30 ppm in water column; Ni has 33-39 ppm in sediment and 40-50 ppm in water column; Cd has 5.9-8 ppm in sediment and 8.5-15 ppm in the water column. The heavy metals, TSS, and water river discharge have balance-decay pattern. The amount of river water discharge entering Jakarta Bay, the heavy metals, and the low level of ocean currents cause coastal waters of Jakarta Bay to become muddy puddles that cannot flow properly. These conditions make the mangrove forest habitat becomes polluted and the mangrove vegetation degraded. Therefore, all of these things need to get serious attention so the mangrove forests can be restored and the function of mangroves can return to normal.
\end{abstract}

Keywords: Balance-decay pattern, Important Value Index, leverage parameters, reinforced-exponential growth pattern.

\section{INTRODUCTION}

The coastal area of Jakarta Bay has experienced relatively high land cover changes. In a decade, the land cover had reduced from 340,90 ha in 1997 to 232,04 in 2006, equating $31.93 \%$ loss (Parawansa 2007). This change is mainly caused by land degradation with human as the main driver as indicated by many studies such as Permanawati et al. (2013), Kusuma et al. (2014), KLHK and Plarenco (2015), Breckwoldt et al. (2016), Ladwig et al. (2016), Simon et al. (2016), Sindern et al. (2016), Siregar et al. (2016), Dsikowitzky et al. (2018), and Latief et al. (2018).

The existence of mangrove vegetation in coastal areas plays important roles. First main function is the protection function including improving water management, preventing seawater from intrusion and pollution, protecting from wind and abrasion of the beach, and maintaining habitat of aquatic and terrestrial biota. The second function is maintaining the purity and uniqueness of genetic diversity of species and mangrove forest ecosystems (Parawansa 2007).

The position of Jakarta Bay, which is the estuary of 13 rivers, bring very large environmental pressures coming from various human activities, such as industries, hotels and restaurants, settlement, and coastal area development (Dsikowitzky et al. 2018). As a consequence, mangrove forest located on its beaches has been exposed to pollutants, garbage accumulation, and sedimentation. The current condition of Jakarta Bay shows that this area is very sensitive to ecosystem vulnerability (KLHK and Plarenco 2015). Therefore, to sustain the condition of Jakarta Bay, 
one effort is to conserve the mangrove forest optimally and systematically. However, the mangrove forests in Jakarta Bay are threatened by deforestation and land conversion which affects community structure of the mangroves in Jakarta Bay. There are three types of mangrove vegetation in disturbed areas of the Jakarta Bay. Avicennia and Rhizophora are genera of mangrove vegetation which are mostly grown in flooded areas on the coastal, while Sonneratia is a genus often found in river estuaries. Avicennia, Rhizophora, and Sonneratia can live in areas with high environmental stress and are able to adapt to poor conditions.

This study aims to analyze the responses of Avicennia, Rhizophora, and Sonneratia to water quality based on the structure of mangrove community in disturbing areas in Jakarta Bay predicted using system dynamics modeling. The significance of this study is expected to provide baseline information on the management of mangrove forests in Jakarta Bay including the importance of restoration of the main function of the mangrove forest.

\section{MATERIALS AND METHODS}

\section{Study area and period}

The research was conducted in Jakarta Bay, Indonesia areas in years of 2016 (one year), encompassing Tangerang (Banten Province), North Jakarta (Jakarta Province), and Bekasi (West Java Province). The research locations were divided into five stations where Station-1 (Sta-1) was located in Dadap (Tangerang) at latitude 605'13.78 "S and longitude 106 ${ }^{\circ} 3^{\prime} 11.94 "$ E; Station-2 (Sta-2), Station-3 (Sta-3), and Station-4 (Sta-4) were located in North Jakarta at latitude and longitude of 6 ${ }^{\circ} 5^{\prime} 59.09$ "S and 106 $44^{\prime} 18.45^{\prime \prime} \mathrm{E}$, $6^{\circ} 6^{\prime} 2.34$ "S and 106 44'52.89" E, 6º $6^{\prime} 15.29$ "S and $106^{\circ} 45^{\prime} 34$. $^{\prime \prime}$ " E, respectively; and Station-5 (Sta-5) was located in Muara Bendera (Bekasi) at latitude 5०56'18.63 "S and longitude $106^{\circ} 59^{\prime} 25.78^{\prime \prime} \mathrm{E}$.

\section{Procedures}

Data on the field were collected using line transect method with length of the line was $100 \mathrm{~m}$. Three plots of quadrant were then established with size of $10 \times 10 \mathrm{~m}^{2}$ and distance between quadrants was $20 \mathrm{~m}$. The mangroves within the plots have identified the species, measured the stem diameter, and counted the number of individual at each life stage/level (i.e. trees, saplings, and seedlings). These procedures were applied across the five stations. The data were brought into laboratory and analyze the structure of mangrove community.

The data of water and sediment quality were also collected after the sampling of vegetation analysis. The samples of water were brought using portable tools and analyzed in laboratory, while the sediment analysis used soil mechanic laboratory. All collected data including the structure of mangrove community and water quality were then analyzed by simulation using system dynamics modeling with Powersim Studio 10 software.

\section{Data analysis}

Vegetation structures of mangroves were analyzed by calculating the relative density, relative frequency, relative closure, and important value index (IVI). The water quality was analyzed by measuring pH, Dissolved Oxygen (DO), Total Suspended Solid (TSS), salinity, temperature, rainfall, turbidity, and grain size analysis. System dynamic modeling was used to investigate trend analysis of IVI mangrove in response to water quality.
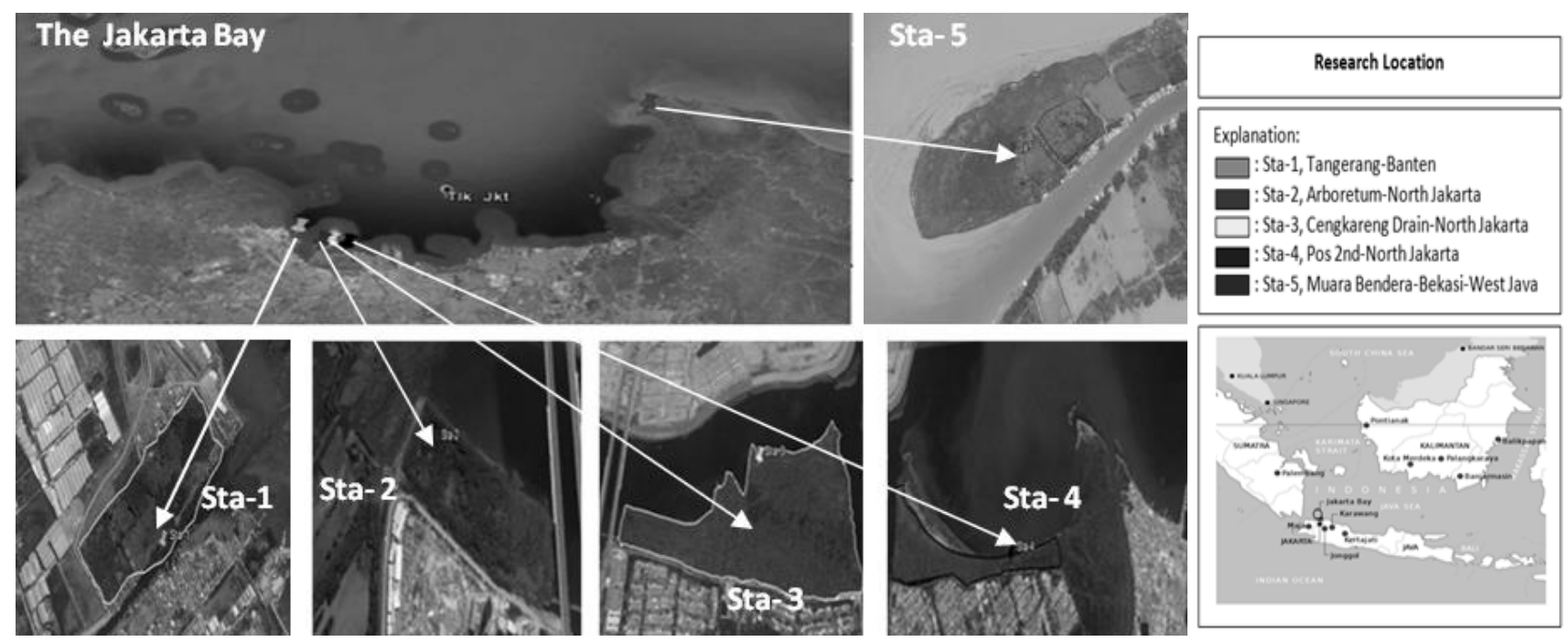

Figure 1. Research locations in Jakarta Bay areas, Indonesia. Station 1 (Sta-1) was located in Tangerang, Banten province; Station 2 (Sta-2), Station 3 (Sta-3) and Station 4 (Sta-4) were located in North Jakarta, Jakarta Province; while Station 5 (Sta-5) was located in Bekasi, West Java Province 


\section{RESULTS AND DISCUSSION}

\section{The structure of mangrove community}

The result of the structure of mangrove community in the research locations is presented in Table 1. The results of relative density, relative frequency, relative closure, and important value index (IVI) in Table 1 combine all the five stations for each level of life stage (trees, saplings, and seedlings).

Table 2 shows the dominant species of mangrove across the five stations in which species from the genera of Avicennia, Rhizophora, and Sonneratia have the highest IVI. Sta-1 until Sta-4 were disturbed by human activities either in the terrestrial and ocean areas, while Sta-5 was less disturbed with some parts were undisturbed.

The dominance of a species indicates the adaptive ability of such species in a polluted habitat. The species presented in Table 2 are those of trees, saplings, and seedlings dominant. The dominant are Avicennia marina, Avicennia lanata, Rhizophora apiculata, and Sonneratia caseolaris.

The species of mangrove found in the five research stations in this study is lower than previous study by Sukardja (1982). He mentioned that there were 11 dominant species in Muara Angke (Sta-2 until Sta-4) including Avicennia marina, A. alba, A. officinalis, Rhizophora apiculata, R. mucronata, Bruguiera parviflora, Sonneratia alba, and Excoecaria agallocha. The Bekasi area (Sta-5) was dominated by Avicennia, Rhizophora, and Sonneratia while in Tangerang area (Sta-1) was dominated by Rhizophora and Nypa. Our results combined with the study by Sukardja (1981) shows the changes in the structure of mangrove community from the $1980 \mathrm{~s}$ to present. The reduced number of surviving species demonstrates natural selection of species due to habitat degradation condition in Jakarta Bay.

\section{The quality of water in mangrove habitat}

Measuring water quality describes the condition of mangrove habitat in term of its physical and chemical properties. The parameters of DO, brightness, TSS, salinity indicate that the habitat in the study locations are relatively not suitable for mangrove growth, while temperatures and $\mathrm{pH}$ are within the range (Table 3). The $\mathrm{pH}$ inside habitat mangrove was around 7-8 while outside habitat was around 3-4. A large volume of solid waste has made the estuaries around Jakarta Bay become dirty and unpleasant to see, and caused the pollutants to sink into the sediment.

Table 1. The structure of mangrove community in Jakarta Bay, Indonesia for each level of life stage

\begin{tabular}{lccc}
\hline \multirow{2}{*}{ Level } & \multicolumn{2}{c}{ The structure of mangrove community } \\
\cline { 2 - 4 } & $\begin{array}{c}\text { Relative Density of } \\
\text { species (i) }(\mathbf{R D i})(\boldsymbol{\%})\end{array}$ & $\begin{array}{c}\text { Relative Frequency } \\
\text { species (i) }(\mathbf{R F i})(\boldsymbol{\%})\end{array}$ & $\begin{array}{c}\text { Relative Closure species } \\
(\mathbf{i})(\mathbf{R C i})(\boldsymbol{\%})\end{array}$ \\
\hline Tree & 35.18 & 29.99 & 47.34 \\
Sapling & 28.82 & 29.52 & 39.22 \\
Seedling & 22.55 & 28.14 & 29.32 \\
Average & 28.85 & 29.21 & 38.62 \\
\hline
\end{tabular}

Table 2. The dominant species at tree, sapling and seedling at study locations in Jakarta Bay, Indonesia

\begin{tabular}{|c|c|c|c|c|c|c|}
\hline Sta. & Dominant species & & & & & \\
\hline & Tree & Average IVI & Sapling & Average IVI & Seedling & Average IVI \\
\hline 1 & Rhizophora aviculata & 145.96 & Avicennia marina & 115.04 & Avicennia marina & 102.64 \\
\hline 2 & Avicennia lanata & 125.79 & Avicennia marina & 127.39 & Avicennia marina & 129.56 \\
\hline 3 & Rhizophora apiculata & 104.32 & Avicennia lanata & 104.56 & Rhizophora apiculata & 78.51 \\
\hline 4 & Avicennia marina & 124.99 & Avicennia marina & 127.18 & Avicennia marina & 102.29 \\
\hline 5 & Sonneratia caseolaris & 133.19 & Sonneratia caseolaris & 126.56 & Sonneratia caseolaris & 106.04 \\
\hline
\end{tabular}

Table 3. Water quality in five study locations in Jakarta Bay, Indonesia

\begin{tabular}{|c|c|c|c|c|c|c|c|c|}
\hline \multirow{2}{*}{ Parameters } & \multirow{2}{*}{ units } & \multirow{2}{*}{ Tools } & \multicolumn{5}{|c|}{ Stations } & \multirow{2}{*}{$\begin{array}{c}\text { *Standard } \\
\text { quality }\end{array}$} \\
\hline & & & Sta-1 & Sta-2 & Sta-3 & Sta-4 & Sta-5 & \\
\hline Temperature & ${ }^{\circ} \mathrm{C}$ & Thermometer & 28.36 & 29.03 & 27.03 & 30.23 & 26.13 & Natural \\
\hline $\mathrm{pH}$ & - & $\mathrm{pH}$ meter & 7.3 & 8 & 7.3 & 8.1 & 8.07 & $7-8.5$ \\
\hline DO & $\mathrm{mg} / \mathrm{L}$ & DO meter & 7.4 & 3.5 & 0.13 & 4.5 & 7.9 & $>5$ \\
\hline Turbidity & $\mathrm{m}$ & Secci dish & 6 & 6 & 5 & 5 & 3 & $>6$ \\
\hline TSS & $\mathrm{mg} / \mathrm{L}$ & Ex-situ & 51.25 & 48.76 & 43.33 & 59.96 & 51.45 & 20 \\
\hline Salinity & $\%$ & Refractometer & 6 & 8 & 9 & 5 & 5 & 34 \\
\hline Solid waste ${ }^{* *}$ & - & & +2 & +2 & +4 & +4 & - & 0 \\
\hline
\end{tabular}

Note: * Decree of the Minister of Environment No.51/2004. **Measurement of solid waste: $0=$ None; $1=$ Very small volume; $2=$ Small volume; $3=$ Moderate; 4 = Large volume; 5 = Very large volume (Full coverage) 
The hydro-oceanographic measurements including the average current velocity were $0.04-0.08 \mathrm{~m} / \mathrm{s}$, the tides were single type with short waves generated by wind, the discharge from 13 rivers were $205 \pm 97 \mathrm{~m}^{3} / \mathrm{s}$ and the water discharge from the power plant were $224.9 \mathrm{~m}^{3} / \mathrm{s}$. The heavy metals concentrations are presented in Table 4 which divided the resources either from terrestrial and marine. The result showed that the sources from terrestrial give larger pollution than those from marine.

The analysis of grain size shows that the sediments in the study locations in Jakarta Bay are dominated by mix of clay and sand (Figure 2).

The composition of sediment type and the dominance of mangrove species at each station is described in Table 5. This Table is used to understand the relationship between dominant species that could adapt in habitat with varying conditions of sediment type.

\section{The analysis of mangrove responses on disturbed area}

The response of mangrove in disturbed area was modeled using simulation of system dynamic with the results presented in Figure 3. This simulation was used to predict how the mangrove would response in the future with assumption that the condition is the same as the time when this research was carried out (i.e. business as usual).

The model was set to predict condition 24 months in the future because the data were taken in one year. Each model run was validate using absolute mean error (AME). For environmental scale, the model was said to be valid if $\mathrm{AME}<0.3$ while for laboratory scale, the model would be said to be valid if the AME $<0.1$. The formula of AME:

Absolute Mean Error $(\mathrm{AME})=(\mathrm{S}-\mathrm{R}) / \mathrm{R}$

Whereas:
$\mathrm{S}=$ Simulation
$\mathrm{R}=$ Reference

The result of AME for $\mathrm{pH}$ was 0.13 ; temperature 0.09 ; rainfall 0.13; salinity 0.15; Total Suspended Solid 0.07; Disolved Oxygen 0.07 ; brightness 0.08 ; sediment 0.09 ; heavy metal 0.14 ; ocean current 0.07 ; water river discharge 0.06. All results indicate that the AME are under 0.3 so it can be said that all models designed were valid and useable.

\section{Discussion}

Our study found that mangrove community structures at five locations in Jakarta Bay were dominated by Avicennia marina, followed by Avicennia lanata, Rhizophora apiculata, Sonneratia caseolaris, and Sonneratia alba at the level of trees and saplings. At seedling stage, the dominant species were Acrostichum aureum and Acanthus ilicifolius. The Avicennia genus was located in the frontier of coastal zone and resistant to environmental stress (Martuti et al. 2016). Behind it is the Rhizophora group. Avicennia marina and other species from Avicennia genus are species of mangrove pioneer plants and have the ability for phytoremediation because of its ability to survive in polluted environments (MacFarlane et al. 2003; Usman et al. 2013; Martuti et al. 2016). Therefore, it is not surprising if Avicennia is in the frontier zones. However, their response to water quality could decrease, mean that they have a maximum threshold to adapt to bad environment, and if pollution continues, their adaptability would decrease (MacFarlene and Burchett 2000; Martuti et al. 2016; Crugati et al. 2018; Latief et al. 2018) which is in agreement with the result of our study as shown in Figure 3.

Table 4. The concentration of heavy metals in sediments and water columns and their sources in Jakarta Bay, Indonesia (Kusuma et al. 2014)

\begin{tabular}{lrrcc}
\hline \multirow{2}{*}{$\begin{array}{c}\text { Heavy } \\
\text { metal }\end{array}$} & \multicolumn{2}{c}{ Concentration (ppm) } & \multicolumn{2}{c}{ Source } \\
\cline { 2 - 5 } & Sediment & $\begin{array}{c}\text { Water } \\
\text { column }\end{array}$ & Terrestrial & Marine \\
\hline $\mathrm{Pb}$ & $65-104$ & $38-60$ & + & \\
$\mathrm{Zn}$ & $150-258$ & $42-140$ & + & \\
$\mathrm{Cu}$ & $34-72$ & $13-30$ & + & \\
$\mathrm{Ni}$ & $33-39$ & $40-50$ & & + \\
$\mathrm{Cd}$ & $5.9-8.0$ & $8.5-15$ & & + \\
\hline
\end{tabular}

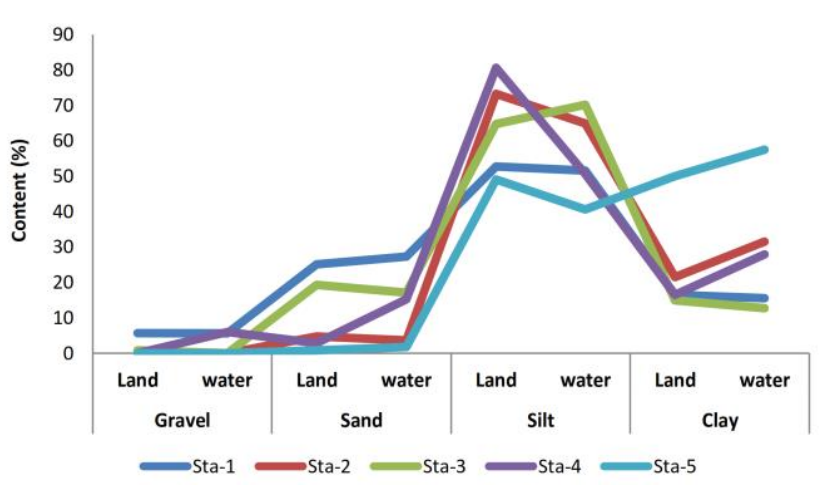

Figure 2. The analysis of grain size of sediment in coastal areas in Jakarta Bay, Indonesia

Table 5. The composition of sediment type and the dominant species in coastal areas of Jakarta Bay, Indonesia

\begin{tabular}{lccccll}
\hline Station & Gravel & Sand & Silt & Clay & Dominant species & IVI \\
\hline Sta-1 & 1 & 5 & 9 & 3 & A.marina $\left(5^{*}\right)$, A. lanata $\left(1^{*}\right)$ \\
Sta-2 & 1 & 10 & 163 & 63 & R. apiculata $(2 *)$. A. lanata $(3 *)$. A. marina $(1 *)$ & $132.23-164.72$ \\
Sta-3 & 1 & 20 & 75 & 15 & A.lanata $(2 *)$, R. apiculata $(4 *)$. & $116.55-173.99$ \\
Sta-4 & 1 & 1,5 & 11 & 4 & A.marina $(6 *)$ & $105.73-161.79$ \\
Sta-5 & 0 & 1 & 33 & 37 & S. caseolaris $(5 *)$. S.alba $(1 *)$ & $118.76-160.43$ \\
\hline
\end{tabular}

Note: *the average number of species found in each plot on each station 

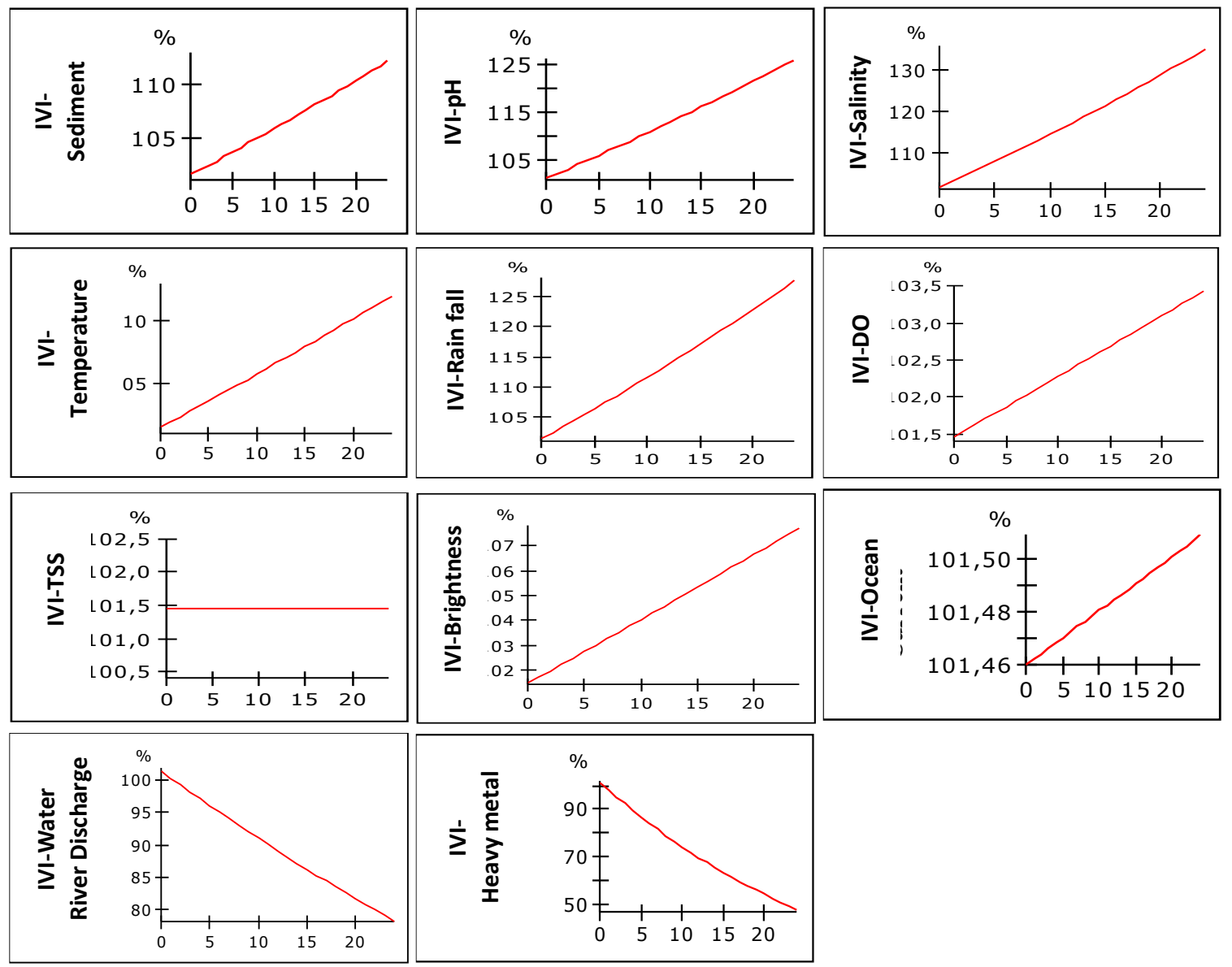

Figure 3. Relationships between important value index of mangroves and the parameters of water quality in disturbed areas in Jakarta Bay (Y-axis), while $\mathrm{X}$-axis refer to times in month

The low value of IVI of mangrove vegetation in all stations was likely a response to the condition of the waters in Jakarta Bay which were polluted by heavy metals, both from the land and from the waters (Table 3) (Permanawati and Ibrahim 2013; Kusuma et al. 2014; Siregar et al. 2016; Sinern et al. 2016; Lohr et al. 2017; Latief et el. 2018). The ocean currents of $0.04-0.08 \mathrm{~m} / \mathrm{s}$ combined with water from 13 rivers flowing into Jakarta Bay at the volume of 216.84 $\mathrm{m}^{3} / \mathrm{s}$ and the inlet/outlet discharge from electricity power plant with the volume of $224.9 \mathrm{~m}^{3} / \mathrm{s}$ (Setiawan 2016), have caused the coastal waters of Jakarta Bay to become a highly polluted water area with low mobilization (Rinawati 2012; Pranowo and Tim Kajian Reklamasi 2016; Simon et al. 2016; Sindern 2016; Siregar et al. 2016). This makes the water trapped and resembles an inundated pool. As such, it is not surprising that mangrove growth and productivity have decreased. This condition also causes reforestation efforts carried out by stakeholders to stagnate and less successful. Mangrove seeds originating from outside Jakarta Bay were not able to grow well in this area due to the mangrove habitats in Jakarta Bay has been highly contaminated.

In coastal area, heavy metals are returned to external environments through decomposition of mangrove litters. Leaves can accumulate heavy metals through translocation process from roots and stems (MacFarlane et al. 2003; Qiu et al. 2011; Martuti et al. 2018). Sonneratia, as well as Avicennia and Rhizophora, has a way to adapt in highly pressed environment by falling they leave (defoliation) (Qiu et al. 2011; Martuti et al. 2016; Rahmania et al. 2018). This process brings back the heavy metals from litters to sediment or the surrounding places.

A large amount of waste in the mangrove habitats in Jakarta Bay suggests that there was poor waste management which can cause the death of both vegetation and animal living around the area (Rinawati et al. 2012; Alimba and Caterina 2019; Mishra and Alok 2019). The accumulated plastic waste, domestic waste, and other solid waste was the effect of high urbanization in Jakarta and its surroundings (Breckwoldt et al. 2016; Dsikowitzky et al. 2018). This problem must be addressed, otherwise, it will impact the conservation, economic, and social aspects (Sindern et al. 2016; Lohr et al. 2017; Latief et al. 2018; Chung et al. 2019; Mishra et al. 2019).

Grain size analysis showed that the composition of the sediment of mangrove habitat in Jakarta Bay was dominated by silt with a mixture of clay and sand (Figure 2). Avicennia marina and Avicennia lanata could grow well in sediment dominated by silt with a mixture of clay and sand on a small ratio (Table 5). While Rhizophora 
apiculata has more dominantly grown in sediments of silt with a mixture of sand and clay on a large ratio. Sonneratia caseolaris and Sonneratia alba could grow in sediments of clay with a silt ratio greater than sand. The low IVI value in Sta-3 and Sta-4 were dominated by Avicennia marina and Avicennia lanata with habitats composed by silt sediments with almost balanced clay and sand mixtures. Sediment composition determines the species of mangrove vegetation that could grow since each mangrove species give different response on the ability of mangrove root to bind substrates. This difference is also influenced by the rate of deposition of the substrate affected by physical factors such as ocean currents, waves, rainfall, and temperature. While chemical factors affect the growth of mangrove vegetation in binding sedimentary substrate (Rinawati 2012). All the conditions mentioned above relate to the changes in mangrove community structures occur in Jakarta Bay. This explains the succession of several mangrove species in regard to their adaptation to changes in the physical and chemical conditions in the waters of Jakarta Bay. In addition to the composition, it is also seen the condition of seawater pollution that changes the quality of water in Jakarta Bay.

Jakarta Bay accommodates 13 rivers flowing into the waters of the bay. Every year, the 13 rivers carry 46 tons of sediment into the waters of the Jakarta Bay. Therefore the composition of grain size in sediments is important to observe. The waters of Jakarta Bay are contaminated with pollution and affect the life of mangroves in the bay. The responses of some dominant species will determine the future succession of mangrove forests in Jakarta Bay.

The result of simulation suggests that the important value index (IVI) of Avicennia, Rhizophora, and Sonneratia show a reinforced pattern in response to water quality conditions in Jakarta Bay (Figure 3). Sediment, salinity, DO, TSS, brightness, ocean currents, and temperature parameters could cause reinforced behavior of IVI mangroves with slow growth. On the contrary, water river discharge and heavy metal parameters could balance the IVI value of mangrove in trend of decay. Important value index of mangroves in Jakarta Bay resembles natural selection process experienced by a species by showing relative density, relative frequency and relative closure which leads to how this species dominates the structure of a community as an adaptive response to habitat conditions. In other words, the important value index describes the ecological position of a species in a community by looking at the dominance of a species against others.

As explained earlier that the quality of seawater in Jakarta Bay has decreased due to human activities, the contamination of heavy metals leads to a decrease in the important value index of mangroves. The polluted waters cause several mangrove species cannot live although there are also other mangrove species that are able to adapt to the disturbed habitats. There has been a shift in the structure of mangroves from the past to nowadays. Dominance arises, but growth slows down due to habitat disturbance. Many seedlings and saplings were not able to grow well, resulting in high mortality, while at the tree level the value of IVI was small and it grew slowly. The flow of 13 rivers in the waters of Jakarta Bay bring 46 tons of sediment each year.
With small currents, these sediments were contaminated with dangerous dissolved particles, eventually changing the composition of matters in mangrove habitat restricting several mangrove species to grow in the area. Reduction in the number of species and changes in species dominance demonstrate a shift in mangrove structure in Jakarta Bay.

In conclusion, the mangrove community in five locations in Jakarta Bay was dominated by the species from the genera of Avicennia, Rhizophora, and Sonneratia. Mangrove community structures in this area reinforce slowly along with the increase in pollution and decrease in water quality, especially for $\mathrm{pH}$, temperatures, rainfall, brightness, dissolved oxygen, total suspended solids, sediment, and ocean current. The trend was worsened by heavy metals accumulation and water river discharge. The mangrove species in Jakarta Bay have the ability to neutralize the $\mathrm{pH}$ of water indicated by the value of $\mathrm{pH}$ was around 7-8 inside the habitat and while outside the habitat the value of $\mathrm{pH}$ was around 3-4. Nonetheless, some species of mangrove are able to adapt to the conditions of waters contaminated by heavy metals. This ability is inherited continuously so that the dominant species can grow in contaminated habitats although with slow growth.

\section{ACKNOWLEDGEMENTS}

We thank Sekolah Tinggi Teknologi Industri Bontang (STTIB), East Kalimantan Province, Indonesia for providing the opportunity to continue study and conduct the research. We thank the Postgraduate Department of Biology, University of Indonesia which has given the opportunity to carry out this research and provided laboratory facilities so that this research can run smoothly. Thanks also to the Indonesia Endowment Fund for Education (LPDP/Lembaga Pengelola Dana Pendidikan) from the Ministry of Finance Republic of Indonesia which funded this research until this research was successfully completed.

\section{REFERENCES}

Alimba CG, Caterina F. 2019. Microplastics in the marine environment: current trend in environmental pollution and mechanisms of toxicological profile. Environ Toxicol Pharmacol. DOI: 10.1016/j.etap.2019.03.001

Breckwoldt A, Larissa D, Gunilla B, Sebastian CAF, Simon vdW, Ima K, Andrian R, Luky A. 2016. A review of stressors, uses and management perspectives for the larger Jakarta Bay Area, Indonesia. Mar Pollut Bull 110 (2): 790-794.

Carugati L, Beatrice G, Eugenio R, Marco LM, Caterina C, Silvestro G, Roberto D. 2018. Impact of mangrove forests degradation on biodiversity and ecosystem functioning. Sci Rep 8: 13298. DOI: 10.1038/s41598-018-31683-0.

Cebe K, Lale B. 2018. Monitoring and modeling land-based marine pollution. Regional Stud Mar Sci 24: 23-39.

Chung LC, Tuey CL, Chien HL. 2019. Beyond sectoral management: enhancing Taiwan's coastal management framework through a new dedicated law. Ocean Coast Manag 169: 157-164.

Dsikowitzky L, Simon A vdW, Dwiyitno, Ariyani F, Karl-JH, Ario D, Jan S. 2018. Transport of pollution from the megacity Jakarta into the ocean: Insight from organic pollutant mass fluxes along the Ciliwung river. Estuar Coast Shelf Sci 215: 219-228. 
Kementerian Lingkungan Hidup dan Kehutanan \& PT. Plarenco. 2015. Album peta kepekaan lingkungan wilayah pesisir dan laut Teluk Jakarta. Jakarta. [Indonesian]

Kusuma AH, Prartono T, Atmadipoera AS, Arifin T. 2014. Sebaran polutan logam berat terlarut dan sedimen di perairan Teluk Jakarta, dalam Poernama A, Sulistiyo B, Wirasantoso S, Brodjonegoro IS (eds.). Dinamika Teluk Jakarta: Analisis prediksi dampak pembangunan tanggul laut Jakarta (Jakarta Giant Sea Wall). Badan Penelitian dan Pengembangan Kelautan dan Perikanan Kementerian Kelautan dan Perikanan. IPB Press. Jakarta. [Indonesian]

Ladwig N, Karl-JH, Simon A.vdW, Ario D, Daniela K. 2016. Pressureon oxygen levels of Jakarta Bay. Mar Pollut Bull 110 (2): 665-674.

Latief H, Mutiara RP, Farrah H, Ika NA, Muhammad F, Dominic I. 2018. Costal hazard assessment in northern part of Jakarta. Procedia Eng 212: 1279-1286.

Lohr A, Heidi S, Raoul B, Marco K, Ad Ragas, Frank VB. 2017. Solution for global marine litter pollution. Curr Opin Environ Sustain 28: 90

Martuti NKT, Wiianarko B, Yulianto B. 2016. Eliminasi logam Cu oleh serasah Avicennia marina di lingkungan tambak bandeng wilayah tapak Tugurejo, Semarang. Manusia dan Lingkungan 23 (3): 304-309. [Indonesian]

MacFarlane GR \& Burchett MD. 2000. Cellular distribution of copper, lead and zinc in the grey mangrove, Avicennia marina (Forsk.) Vierh. Aquat Bot 68: 45-59.

MacFarlane GR, Pulkownik A, Burchett MD. 2003. Accumulation and distribution of heavy metals in the grey mangrove Avicennia marina (Forsk.) Vierh.: Biological indication potential. Environ Poll 123 139-151.

Mishra S, Chandi CR, Alok PD. 2019. Marine microfiber pollution: A review on present status and future challenges. Mar Pollut Bull 140: 188-197.

Parawansa I. 2007. Pengembangan Kebijakan Pembangunan Daerah Dalam Pengelolaan Hutan Mangrove di Teluk Jakarta Secara Berkelanjutan. [Disertasi]. Sekolah Pascasarjana Institut Pertanian Bogor (IPB), Bogor. [Indonesian].

Permanawati Y, Zuraida R, Ibrahim A. 2013. Kandungan logam berat $(\mathrm{Cu}, \mathrm{Pb}, \mathrm{Zn}$, dan $\mathrm{Cr}$ ) dalam air dan sedimen di Perairan Teluk Jakarta Puslitbang Geologi Kelautan. Geologi Kelautan 11 (1): 9-16. [Indonesian]

Pranowo W, Tim Kajian Reklamasi. 2016. Hidrodinamika Tanggul Raksasa Teluk Jakarta dan Pulau Reklamasi. Pusat Penelitian dan Pengembangan Sumber Daya Laut dan Pesisir (P3SDLP) Balitbang Kementerian Kelautan Perikanan. Jakarta. [Indonesian]
Qiu YW, Yu KF, Zhang G, Wang WX. 2011. Accumulation and partitioning of seven trace metals in mangroves and sediment cores from three estuarine wetlands of Hainan island, China. J Hazard Mater 190: 631-638.

Rahmania N, Herpandi, Rozirwan. 2018. Phytochemical test of mangrove Avicennia alba, Rhizophora apiculata, and Sonneratia alba from Musi river estuary, South Sumatera. Biovalentia 4 (2): 1-8.

Rinawati, Tatsuya K, Hiroaki K, Rina K, Maki I, Shigeaki S, Ayako T, Mahua S, Zainal A, Hideshige T. 2012. Distribution, source identification, and historical trends of organic micropollutants in coastal sediment in Jakarta Bay, Indonesia. J Hazard Mater 217-218: 208-216.

Setiawan A. 2016. Simulasi model hidrodinamika dan disperse termal di Teluk Jakarta pra dan pasca reklamasi 17 pulau. Laporan teknis bidang hidrodinamika dan geomorfologi tim kajian kegiatan reklamasi balitbang KP. Pusat Penelitian dan Pengembangan Sumberdaya Laut dan Pesisir, Badan Penelitian dan Pengembangan Kelautan dan Perikanan, Kementerian kelautan dan Perikanan. Jakarta. [Indonesian]

Simon A vdw, Ario D, Norbert L, Karl-JH. 2016. Numerical simulations of river discharges, nutrient flux and nutrient dispersal in Jakarta Bay, Indonesia. Mar Pollut Bull 110 (2): 675-685.

Siregar TH, Nandang P, Ajeng KP, Novalia R, Radestya T, Larissa D, Jan S. 2016. Spatial distribution and seasonal variation of he trace hazardous element contamination in Jakarta Bay, Indonesia. Mar Pollut Bull 110 (2): 634-646.

Sindern S, Martin T, Larissa D, Lars G, Jan S, Tuti HS, Farida A, Hari EI. 2016. Heavy metals in river and coast sediments of the Jakarta Bay region (Indonesia)-Geogenic versus anthropogenic sources. Mar Pollut Bull 110 (2): 624-633.

Sukardjo S. 1982. Mangroves of the Jakarta Bay need conservation. Duta Rimba 3 (51): 3-5.

Thomas N, Lucas R, Bunting P, Hardy A, Rosenqvist A. 2017. Distribution and drivers of global mangrove forest change, 19962010. PLOS ONE 12 (6): e $0179302 . \quad$ DOI: 10.1371/journal.pone.0179302.

Tiquio MGJP, Nicolas M, Patrice F. 2017. Management frameworks for coastal and marine pollution in the European and Southeast Asian regions. Ocean Coast Manag 135: 65-78.

Usman ARA, Alkredaa RS, Al-Wabel MI. 2013. Heavy metal contamination in sediments and mangroves from the coast of red sea: Avicennia marina as potential metal bioaccumulator. Ecotoxicol Environ Saf 97: 263-270. 